\title{
Increase in metal extractability after liming of sacrificial sewage sludge disposal soils
}

\author{
JH van der Waals ${ }^{1 *}$, HG Snyman ${ }^{2}$ and AS Claassens ${ }^{1}$ \\ ${ }^{1}$ Department of Plant Production and Soil Science, University of Pretoria, Pretoria 0002, South Africa \\ ${ }^{2}$ Golder Associates Africa (Pty) Ltd., PO Box 6001, Halfway House 1685, South Africa
}

\begin{abstract}
A sandy and a sandy clay-loam soil from two dedicated (sacrificial) sewage sludge disposal sites were incubated with a total lime equivalent of $45 \mathrm{Mg}^{-h^{-1}}$. Both these soils were acidified (pH 4.0 to 4.2 ) and had a significant accumulation of organic material (organic $\mathrm{C}$ of 2.9 to $3.7 \%$ ) compared to non-polluted soils (organic $\mathrm{C}$ of 0.6 to $1.0 \%$ ). The limed soils did not attain the desired $\mathrm{pH}$ of 6.5 after 6 months' incubation due to a high buffer capacity. After incubation, soil samples were taken from the incubated pots and the levels of $\mathrm{Al}, \mathrm{Fe}, \mathrm{Mn}, \mathrm{Cu}, \mathrm{Zn}, \mathrm{Pb}$ and $\mathrm{Cd}$ were determined by atomic absorption spectrophotometry (AAS) after extraction with $\mathrm{NH}_{4}$-EDTA and $\mathrm{BaCl}_{2}$. Most of the metals extracted with $\mathrm{BaCl}_{2}$ (except $\mathrm{Mn}$ in the sandy soil and $\mathrm{Cd}$ in both soils) decreased after liming. The EDTA-extractable $\mathrm{Mn}, \mathrm{Fe}$, and $\mathrm{Cd}$ in both soils and $\mathrm{Cu}$ and $\mathrm{Pb}$ in the sandy clayloam soil increased after liming, whereas $\mathrm{Al}$ and $\mathrm{Zn}$, decreased in extractability (Statistically significant differences could not be determined for the trial due to the trial not having been designed for the results that were obtained). Similar results were reported in the literature for EDTA metal extraction but the phenomenon was not elaborated upon, except for Cr. The increased extractability of some of the metals after liming could negatively influence the use of EDTA as an extracting agent in proposed heavy-metal guidelines for similar sacrificial soils. Should liming be considered as a strategy to decrease metal mobility in sacrificial soils, the observed increase in extractability becomes a cause for concern and should receive attention in further research.
\end{abstract}

Keywords: sewage sludge, liming, metal extractability, $\mathrm{BaCl}_{2}, \mathrm{NH}_{4}$-EDTA

\section{Introduction}

In recent years, the trend has been to express heavy-metal levels in soils as plant- or potentially plant-available metal levels (Beckett, 1989; McLaughlin, et al., 2000) rather than "total" concentrations. This implies that "weaker" extractants or chelating agents be used in heavy-metal studies. Ethylenediaminetetraaceticacid (EDTA), in either the di-sodium or di-ammonium salt form, has been used extensively in a host of studies as an extractant of potentially plant-available heavy metals.

In some trials, EDTA was found to give a very good indication of the pollution hazard of heavy metals in soils as well as being a reliable test for predicting plant-available metals (Hooda et al., 1997; Cajuste and Laird, 2000). Earlier, Bruemmer and Van der Merwe (1989) stated that the $\mathrm{NH}_{4}$-EDTA-extractable heavy metal concentration gives a good estimate of those potentially plant-available, and therefore suggested it to be used in the establishment of preliminary threshold values for heavy metals in South African soils. Currently, however, there are no guidelines stipulating the maximum EDTA-extractable metal levels in South African soils.

Neutral salt extractants are generally weaker extractants than EDTA and give an indication of the immediately exchangeable (therefore immediately plant-available) metals (Beckett, 1989; McLaughlin et al., 2000). Examples of such extractants

\footnotetext{
* To whom all correspondence should be addressed.

푱 +2712 420-3214; fax: +2712 420-3221;

e-mail: jvdwaals@postino.up.ac.za

Received 5 July 2004; accepted in revised form 14 January 2005.
}

are $\mathrm{BaCl}_{2}, \mathrm{NH}_{4} \mathrm{NO}_{3}, \mathrm{NH}_{4}$-Acetate buffered at $\mathrm{pH}$ 7, and more. The $\mathrm{BaCl}_{2}$ method (Hendershot and Duquette, 1986) gives an indication of the effective cation exchange capacity (ECEC) of the soil at un-buffered $\mathrm{pH}$ levels. This is particularly relevant in studies where the $\mathrm{pH}$ dependence of metal extractability is one of the parameters of investigation.

In a preliminary study it was found that soils from some sacrificial sewage sludge disposal sites can be acidified ( $\mathrm{pH} 4.0$ to 4.2) and also have very high pH-buffering capacities due to relatively high organic carbon levels (organic $\mathrm{C} \%$ of 2.9 to $3.7 \%$ ). Coupled to this is a significant increase in total heavy metal content of the soil. The aim of this study was to determine the $\mathrm{BaCl}_{2}$ and $\mathrm{NH}_{4}$-EDTA extractability of a range of metals in two acid soils after liming to near-neutral $\mathrm{pH}$ levels and incubation in pots.

\section{Materials and methods}

The buffer capacity of the two acid soils (here referred to as Soils 1 and 2) was determined with a $\mathrm{Ca}(\mathrm{OH})_{2}$, buffer (Van der Waals and Claassens, 2002). The required amount of a commercial dolomitic lime (according to the buffer determination) for a $\mathrm{pH}$ of 6.5 was added to each soil in $7.5 \mathrm{~kg}$ pots (with 4 repetitions) and the soil incubated for 3 months with regular watering and mixing. After sampling the soil and finding only a slight change in $\mathrm{pH}$ it was decided to add an equal amount of lime and incubate the soil again for the same period of time. The total amount of lime added amounted to the equivalent of $45 \mathrm{Mg} \cdot \mathrm{ha}^{-1}$.

After the second incubation period, a representative sample was taken from each pot and the $\mathrm{pH}$ determined according to the method described by the The Non-Affiliated Soil Analysis 


\begin{tabular}{|l|c|c|c|c|}
\hline \multicolumn{5}{|c|}{ TABLE 1 } \\
Soil 1 and 2 pH values before and after liming (n = 4) \\
\hline Method & \multicolumn{2}{|c|}{ Soil 1 } & \multicolumn{2}{c|}{ Soil 2 } \\
\hline & Before & After & Before & After \\
\hline Water & 4.2 & 5.6 & 4.0 & 5.8 \\
\cline { 2 - 5 } $\mathrm{CaCl}_{2}$ & 3.8 & 5.3 & 3.7 & 5.7 \\
\cline { 2 - 5 } $\mathrm{KCl}$ & 3.3 & 5.0 & 3.5 & 5.4 \\
\hline
\end{tabular}

\begin{tabular}{|c|c|c|c|c|}
\hline \multicolumn{5}{|c|}{$\begin{array}{c}\text { TABLE } 2 \\
\begin{array}{c}\text { The effect of liming on } \mathrm{BaCl}_{2} \text { extractable metals }\left(\mathrm{mg} \cdot \mathrm{kg}^{-1} \text { soil; } \mathrm{n}=4 \text {; values in }\right. \\
\text { brackets denote the standard deviation) }\end{array}\end{array}$} \\
\hline \multirow[t]{2}{*}{ Metal $\left(\mathrm{mg} \cdot \mathrm{kg}^{-1}\right)$} & \multicolumn{2}{|c|}{ Soil 1} & \multicolumn{2}{|c|}{ Soil 2} \\
\hline & Before & After & Before & After \\
\hline $\mathrm{Al}$ & $35.0(1.3)$ & $0.2(0.3)$ & $154.7(6.7)$ & $0.2(0.1)$ \\
\hline $\mathrm{Cu}$ & $3.3(0.2)$ & $0.2(0.1)$ & $14.1(0.2)$ & $0.8(0.1)$ \\
\hline $\mathrm{Mn}$ & $17.5(0.5)$ & $21.2(4.0)$ & $29.7(2.0)$ & $12.4(3.0)$ \\
\hline $\mathrm{Fe}$ & $6.0(1.0)$ & $0.5(0.5)$ & $0.8(0.8)$ & $0.3(0.2)$ \\
\hline $\mathrm{Zn}$ & $151.6(6.4)$ & $11.5(3.2)$ & $18.5(0.3)$ & $3.0(0.4)$ \\
\hline $\mathrm{Pb}$ & $1.8(2.7)$ & $1.3(0.7)$ & $1.6(1.9)$ & $0.3(0.3)$ \\
\hline $\mathrm{Cd}$ & $0.3(0.2)$ & $0.3(0.1)$ & $0.3(0.2)$ & $0.6(0.1)$ \\
\hline Coefficient of Variation & 5.7 & 25.4 & 5.6 & 24.4 \\
\hline
\end{tabular}

Work Committee (1990). On the limed soil and a sample from the original soil a $\mathrm{BaCl}_{2}$ extraction was done. The method was adapted from Hendershot and Duquette (1986) by agitating $5 \mathrm{~g}$ of soil with $50 \mathrm{~m} \ell 0.1 \mathrm{M} \mathrm{BaCl}_{2}$ in a glass bottle on a horizontal shaker for $1 \mathrm{~h}$. After filtering the solution, the $\mathrm{Al}, \mathrm{Mn}$, $\mathrm{Fe}, \mathrm{Cu}, \mathrm{Zn}, \mathrm{Pb}$, and $\mathrm{Cd}$ contents were determined through AAS. Further, an EDTA extraction (The Non-Affiliated Soil Analysis Work Committee, 1990) was done on the same samples and Al, $\mathrm{Fe}, \mathrm{Mn}, \mathrm{Cu}, \mathrm{Zn}, \mathrm{Pb}$ and $\mathrm{Cd}$ again determined by AAS. The samples were tested at the same time to minimise experimental error differences. The metals $\mathrm{Cr}$ and $\mathrm{Ni}$ were not determined due to the termination of the testing after the first results had yielded unexpected increases upon liming, as discussed below.

\section{Results and discussion}

Table 1 gives the $\mathrm{pH}$ results of the two soils before and after liming. The $\mathrm{pH}$ values increased by $1.4 \mathrm{pH}$ units for Soil 1 and by $1.8 \mathrm{pH}$ units for Soil 2 after the addition of the equivalent of $45 \mathrm{mg} \cdot \mathrm{ha}^{-1}$ lime. This indicates a massive buffering capacity brought about by organic material and complexes stable at $\mathrm{pH}$ 4.2 and 4.0 for Soil 1 and 2 respectively. The buffer determination as described by Van der Waals and Claassens (2002) is therefore considered inadequate for soils with high buffer capacities such as these.

Table 2 indicates the influence of the lime addition and incubation on the $\mathrm{BaCl}_{2}$ extractable metals from the two soils. The metals $\mathrm{Mn}$ and $\mathrm{Cd}$ in Soil 1 and $\mathrm{Cd}$ in Soil 2 did not decrease in extractability after liming as was expected. The expected decrease was found for $\mathrm{Al}, \mathrm{Cu}, \mathrm{Fe}$, and $\mathrm{Zn}$. The large coefficients of variation for the limed soils are indicative of the low values determined for some of the metals that approached their detection limit with AAS

Table 3 indicates the EDTA-extractable metals for the two soils before and after liming. Here most of the tested metals $(\mathrm{Cu}$, $\mathrm{Mn}, \mathrm{Fe}$, and $\mathrm{Cd}$ in both soils and $\mathrm{Pb}$ in Soil 2) did not decrease in extractability and in some cases even increased. Aluminium, $\mathrm{Zn}$, and to a lesser extent $\mathrm{Pb}$ in Soil 1, indicated the expected decrease in extractability.
In a study by Bloomfield and Pruden (1975) an increase in the EDTA extractability of $\mathrm{Cd}, \mathrm{Cu}, \mathrm{Cr}, \mathrm{Ni}, \mathrm{Pb}$, and $\mathrm{Zn}$ in limed sludge samples and an increased extractability of $\mathrm{Cr}$ in limed "sludge + soil samples" was reported. Lake et al. (1984) attributed this increase in $\mathrm{Cr}$ levels to the chemistry of the $\mathrm{Cr}(\mathrm{VI})$ form in soils. In the Bloomfield and Pruden (1975) study, no explanation was given for the increased extractability of metals other than $\mathrm{Cr}$ from the limed sludge samples. Although $\mathrm{Zn}$ decreased in extractability in the present study, the effect of increased extraction was still observed for $\mathrm{Cu}, \mathrm{Mn}, \mathrm{Fe}, \mathrm{Pb}$, and $\mathrm{Cd}$, even though the samples are not exactly of the same type as those in the Bloomfield and Pruden (1975) study.

\section{Conclusions and recommendations}

The results in this trial have led to a number of questions concerning the extractability of the metals and the conditions in the pots. Firstly, although the lime used was a commercially available lime, the metals listed here did not occur at sufficiently high levels to lead to the resultant increase in extractability (data not presented here). It is also not clear whether the lime had reacted completely with the soil. Secondly, the possible fluctuation in $\mathrm{pH}$ during the incubation time is not known and it is therefore impossible to comment on its influence on the metal extractability. Thirdly, the possible mineralisation of organic material after liming could not be quantified due to the set-up of the trial (aerobic conditions in a greenhouse) and it is therefore not possible to comment on its influence on the increased extractability.

Although results similar to these have not been widely reported, the phenomenon warrants further investigation. These authors agree with the conclusions of Lake et al. (1984) concerning the increased Cr extractability in the Bloomfield and Pruden (1975) study, but consider the phenomenon of the increased extractability of the metals other than $\mathrm{Cr}$ as similar to those reported here. The metals that exhibited an increase in extractability do not occur in soil in the same state as $\mathrm{Cr}(\mathrm{VI})$ and therefore require a different explanation.

The trial, having generated a number of questions, was not 
TABLE 3

Effect of liming on $\mathrm{NH}_{4}$-EDTA-extractable metals $\left(\mathrm{mg} \cdot \mathrm{kg}^{-1}\right.$ soil; $\mathrm{n}=4$; values in brackets denote the standard deviation)

\begin{tabular}{|l|c|c|c|c|}
\hline Metal $\left(\mathbf{m g} \cdot \mathbf{k g}^{-1}\right)$ & \multicolumn{2}{|c|}{ Soil 1 } & \multicolumn{2}{c|}{ Soil 2 } \\
\hline & Before & After & Before & After \\
\hline $\mathrm{Al}$ & $113.9(10.4)$ & $33.2(3.8)$ & $337.7(16.5)$ & $222.2(55.6)$ \\
\hline $\mathrm{Cu}$ & $41.1(1.8)$ & $37.1(2.2)$ & $80.8(1.4)$ & $104.6(2.9)$ \\
\hline $\mathrm{Mn}$ & $17.2(0.6)$ & $49.6(3.8)$ & $37.1(5.9)$ & $71.3(6.9)$ \\
\hline $\mathrm{Fe}$ & $242.7(2.7)$ & $383.5(11.9)$ & $170.7(5.6)$ & $271.7(23.9)$ \\
\hline $\mathrm{Zn}$ & $117.0(8.2)$ & $49.1(2.0)$ & $28.8(1.5)$ & $15.6(0.8)$ \\
\hline $\mathrm{Pb}$ & $9.8(0.7)$ & $6.5(0.3)$ & $8.4(2.6)$ & $8.1(1.0)$ \\
\hline $\mathrm{Cd}$ & $0.3(0.02)$ & $0.8(0.2)$ & $0.5(0.01)$ & $1.3(0.1)$ \\
\hline $\mathrm{Coefficient} \mathrm{of} \mathrm{Variation}$ & 4.5 & 4.3 & 5.1 & 13.1 \\
\hline
\end{tabular}

designed to supply the required answers. It is therefore suggested that a dedicated trial be conducted to determine:

- The change in $\mathrm{pH}$ over an extended incubation period with and without the addition of lime with regular sampling intervals

- The change in metal extractability (complexed and exchangeable) over an adequate incubation period with and without the addition of lime with regular sampling intervals

- The EDTA metal extractability as influenced by increasing $\mathrm{pH}$ (lime application rates)

The increased extractability of the metals after the application of lime has a profound influence on the establishment of metal guidelines when EDTA is used. Before the use of EDTA as an extractant in guideline levels is advocated, this phenomenon has to be investigated further to determine the restrictions of the procedure - especially under the conditions experienced in this trial.

\section{Acknowledgements}

The authors wish to express their gratitude to the Water Research Commission (WRC) and ERWAT for funding the project.

\section{References}

BECKETT PHT (1989) The use of extractants in studies on trace metals in soils, sewage sludges, and sludge treated soils. In: STEWART BA (ed.) Advances in Soil Science. Vol. 9. Springer-Verlag, New York. 143-176.

BLOOMFIELD C and PRUDEN G (1975) The effects of aerobic and anaerobic incubation on the extractabilities of heavy metals in digested sewage sludge. Environ. Pollut. 8 217-232.

BRUEMMER GW and VAN DER MERWE D (1989) Report on a visit to the Soil and Irrigation Research Institute, Pretoria, in connection with soil pollution in the RSA and future research requirements. Unpublished report, ISCW, Pretoria.

CAJUSTE LJ and LAIRD RJ (2000) The relationship between phytoavailability and the extractability of heavy metals in contaminated soils. In: ISKANDAR IK (ed.) Environmental Restoration of Metals-Contaminated Soils. Lewis Publishers, Boca Raton, Florida. 189-198.

HENDERSHOT WH and DUQUETTE M (1986) A simple barium chloride method for determining cation exchange capacity and exchangeable cations. Soil Sci. Soc. Am. J. 50 605-608.

HOODA PS, MCNULTY D, ALLOWAY, BJ and AITKEN MN (1997) Plant availability of heavy metals in soils previously amended with heavy applications of sewage sludge. J. Sci. Food Agric. 73 446454.

LAKE DL, KIRK PWW, and LESTER JN (1984) Fractionation, characterization, and speciation of heavy metals in sewage sludge and sludge-amended soils: a review. J. Environ. Qual. 13 175-183.

McLAUGHLIN MJ, ZARCINAS BA, STEVENS DP and COOK N (2000) Soil testing for heavy metals. Commun. Soil Sci. Plant Anal. 31 (11-14) 1661-1700.

THE NON-AFFILIATED SOIL ANALYSIS WORK COMMITTEE (1990) Handbook of Standard Soil Testing Methods for Advisory Purposes. Soil Science Society of South Africa, Pretoria.

VAN DER WAALS JH and CLAASSENS AS (2002) Accurate lime recommendations under South African conditions. Commun. Soil Sci. Plant Anal. 33 (15-18) 3059-3074. 
